\title{
МЕЖБЮДЖЕТНЫЕ ТРАНСФЕРТЫ В СТРУКТУРЕ БЮДЖЕТОВ ЗАКРЫТЫХ АТОМНЫХ ГОРОДОВ - ТЕРРИТОРИЙ НОВОЙ ИНДУСТРИАЛИЗАЦИИ: ЭМПИРИЧЕСКОЕ ИССЛЕДОВАНИЕ
}

\author{
Е. Б. Дворядкина \\ Уральский государственный экономический университет, г. Екатеринбург, Российская Федерация
}

Информация о статье

Дата поступления

14 марта 2018 г.

Дата принятия к печати

21 мая 2018 г.

Дата онлайн-размещения

8 июня 2018 г.

\section{Ключевые слова}

Межбюджетные трансферты; закрытый атомный город; местный бюджет; безвозмездные поступления

\section{Финансирование}

Статья подготовлена при финансовой поддержке РффИ в рамках научного проекта № 18-010-00789А «Разработка методического инструментария исследования экономики нового индустриального города в условиях трансформации пространственной организации экономической деятельности»

\begin{abstract}
Аннотация
Статья посвящена исследованию актуальной научно-практической проблемы фрормирования доходов местных бюджетов закрытых административно-территориальных образований, среди которых особое место занимают закрытые атомные города. Закрытые атомные города как особый тип городских поселений относятся к территориям осуществления новой индустриализации. С позиций муниципального устройства закрытые атомные города имеют статус городских округов, органы местного самоуправления которых формируют местные бюджеты. В статье представлены результаты эмпирического исследования доходной части местных бюджетов закрытых атомных городов России, выявлены тенденции и фракторы, влияющие на показатели дотаций, субвенций и субсидий в структуре доходов местных бюджетов. Показано, что, несмотря на уникальный потенциал новой индустриализации, которым обладают закрытые атомные города, межбюджетные трансферты продолжают сохранять свое значение как важнейший источник формирования их местных бюджетов.
\end{abstract}

\section{INTERGOVERNMENTAL TRANSFERS IN THE STRUCTURE OF LIMITED-ACCESS ATOMIC CITIES' BUDGETS AS TERRITORIES OF THE NEW INDUSTRIALIZATION: AN EMPIRICAL STUDY}

\author{
Elena B. Dvoryadkina \\ Ural State University of Economics, Yekaterinburg, the Russian Federation
}

\section{Article info}

Received

March 14, 2018

Accepted

May 21, 2018

Available online

June 8, 2018

\section{Keywords}

Intergovernmental transfers; limited-access atomic city; local budget; uncompensated receipts

\begin{abstract}
The paper studies a relevant scientific and practical problem of formation of local budgets revenues in limited-access localities, and particularly focuses on limited-access atomic cities. Limited-access atomic cities as a specific type of urban settlements are territories of ongoing processes of the new industrialisation. From the perspective of municipal government, limited-access atomic cities enjoy the status of urban districts, where local government is responsible for forming local budgets. The paper presents the results of an empirical research of local budgets' revenues in Russian limited-access atomic cities and reveals trends and factors affecting the amount of grants, subsidies and subventions in the structure of local budgets revenues. The author demonstrates that despite a unique potential for the new industrialisation possessed by limited-access atomic cities intergovernmental transfers retain their importance as the most significant source for formation of their local budgets.
\end{abstract}


This work was prepared with the financial support of the Russian Foundation for Basic Research within the project no. 18-01000789A «Development of the methodological toolkit for studying the economy of a new industrial city in conditions of transformation of economic activities spatial organisation»

Закрытые атомные города с полным правом можно отнести к территориям осуществления новой индустриализации, так как именно в них сконцентрировано высокотехнологичное промышленное производство (атомная промышленность), организована научная деятельность, сопровождающая атомную промышленность, происходит создание и внедрение в промышленное производство инноваций, нанотехнологий. Совершенно справедливой представляется точка зрения Е. Г. Анимицы, Я. П. Силина и Н. В. Новиковой о том, что именно в атомных городах созданы реальные возможности генерирования и продвижения на внутренние и внешние рынки новых высокотехнологичных инновационных разработок, в том числе в сорере ядерной энергетики, ядерной медицины, радиофармпрепаратов, в области создания мощных лазерных и электротехнических установок и т. п. [1-3]. Закрытые атомные города - это крупные научно-производственные центры, в которых сосредоточены критические технологии и высококвалифицированная конкурентоспособная рабочая сила [4-7].

В Российской Федерации по состоянию на 1 января 2018 г. насчитывается 40 закрытых административно-территориальных образований (ЗАТО), среди которых десять закрытых атомных городов (табл. 1), из них пять расположены на Урале. Перечень ЗАТО и расположенных на их территориях населенных пунктов утвержден постановлением Правительства РФ от 5 июля 2001 г. № 508 (в ред. от 19 апреля 2017 г. № 461).

Закрытые атомные города России

Таблица 1

\begin{tabular}{|c|c|c|c|}
\hline Город & Субъект РФ & Градообразующее предприятие & $\begin{array}{l}\text { Численность постоян- } \\
\text { ного населения } \\
\text { на } 1 \text { января } 2017 \text { г., } \\
\text { тыс. чел. }{ }^{*}\end{array}$ \\
\hline Железногорск & Красноярский край & $\begin{array}{l}\text { ФГУП «Горно-химический комбинат»; } \\
\text { АО «Информационные спутниковые систе- } \\
\text { мы» им. академика М. Ф. Решетнева }\end{array}$ & 93,2 \\
\hline Зеленогорск & Красноярский край & АО «ПО «Электрохимический завод» & 62,5 \\
\hline Саров & $\begin{array}{l}\text { Нижегородская } \\
\text { область }\end{array}$ & $\begin{array}{l}\text { Российский федеральный ядерный центр - } \\
\text { Всероссийский научно-исследовательский } \\
\text { институт экспериментальной физики } \\
\text { (РФЯЦ-ВНИИЭФ) }\end{array}$ & 95,1 \\
\hline Заречный & Пензенская область & ФНПЦ ФГУП «ПО «Старт» & 65,0 \\
\hline Лесной & $\begin{array}{l}\text { Свердловская } \\
\text { область }\end{array}$ & ФГУП «Комбинат «Электрохимприбор» & 51,0 \\
\hline Новоуральск & $\begin{array}{l}\text { Свердловская } \\
\text { область }\end{array}$ & $\begin{array}{l}\text { АО «Уральский электрохимический комби- } \\
\text { нат» }\end{array}$ & 84,2 \\
\hline Северск & Томская область & АО «Сибирский химический комбинат» & 114,3 \\
\hline Озерск & Челябинская область & ФГУП «ПО «Маяк» & 89,7 \\
\hline Снежинск & Челябинская область & $\begin{array}{l}\text { Российский федеральный ядерный центр - } \\
\text { Всероссийский научно-исследовательский } \\
\text { институт технической физики им. академика } \\
\text { Е. И. Забабахина }\end{array}$ & 51,1 \\
\hline Трехгорный & Челябинская область & фГУП «Приборостроительный завод» & 32,4 \\
\hline \multicolumn{4}{|c|}{$\begin{array}{l}\text { "П Показатель численности постоянного населения приведен по: Численность населения Российской Федерации } \\
\text { по муниципальным образованиям на } 1 \text { января } 2017 \text { года [Электронный ресурс] // Бюллетень Федеральной служ- } \\
\text { бы государственной статистики. M., 2017. URL: http://www.gks.ru/wps/wcm/connect/rosstat_main/rosstat/ru/ } \\
\text { statistics/publications/catalog/afc8ea004d56a39ab251f2bafc3a6fce. }\end{array}$} \\
\hline
\end{tabular}


Поскольку ЗАТО создаются как городские округа, то, соответственно, в их ведении находится весь спектр вопросов местного значения, предусмотренных именно для городских округов. Имеется своя специфика и в фрормировании экономической основы местного самоуправления, элементом которой является местный бюджет.

Бюджетная обеспеченность муниципального образования во многом зависит от налоговой базы, которой оно располагает. В связи с тем что статус ЗАТО налагает ограничения, которые подчинены цели обеспечения национальной безопасности государства, введенные ограничения существенным образом сказываются на социально-экономическом развитии закрытых городов, предпринимательской деятельности и инвестиционной активности на их территории, что не позволяет развивать собственную доходную часть муниципального бюджета. Между тем в закрытых атомных городах необходимо на высоком уровне поддерживать производственную и социальную инфраструктуру, формировать и поддерживать комфортную среду проживания и высокие стандарты жизнеобеспече- ния населения, так как за предыдущие десятилетия накоплен человеческий капитал, благодаря которому закрытые атомные города являются точками инновационного роста и территориями осуществления новой индустриализации.

В связи с этим цель исследования провести анализ и дать оценку тенденций и факторов фоормирования и исполнения доходной части местных бюджетов закрытых атомных городов в части межбюджетных трансфрертов.

Основные результаты исследования. На фоне наличия особенностей закрытых атомных городов, обозначенных нами выше, проанализируем тенденции в формировании и исполнении доходной части их местных бюджетов и межбюджетных трансфертов как основного источника поступлений, влияющего на бюджетную обеспеченность. Причем такая ситуация характерна не только для местных бюджетов закрытых атомных городов, но и для муниципальных образований других видов [8-10].

Общие показатели местных бюджетов закрытых атомных городов в 2014-2016 гг. представлены в табл. 2.

Таблица 2

Местные бюджеты закрытых атомных городов в 2014-2016 гг., млн р."

\begin{tabular}{|c|c|c|c|c|c|c|}
\hline \multirow[b]{2}{*}{ Показатель } & \multicolumn{3}{|c|}{ Бюджет на 2014 г. } & \multicolumn{3}{|c|}{ Бюджет на 2016 г. } \\
\hline & Доходы & Расходы & $\begin{array}{l}\text { Десиицит (-), } \\
\text { профицит (+) }\end{array}$ & Доходы & Расходы & $\begin{array}{l}\text { Дефициит (-), } \\
\text { профицит (+) }\end{array}$ \\
\hline \multicolumn{7}{|c|}{ Город Железногорск (Красноярский край) } \\
\hline Местный бюджет, всего & 5400,7 & 5453,6 & $-52,9$ & 3638,9 & 3732,9 & $-94,0$ \\
\hline $\begin{array}{l}\text { Удельный вес в общем объеме } \\
\text { местных бюджетов субъекта } \\
\text { РФ, \% }\end{array}$ & 4,26 & 4,18 & 1,39 & 2,82 & 2,83 & 3,55 \\
\hline $\begin{array}{l}\text { Удельный вес в общем объеме } \\
\text { местных бюджетов городских } \\
\text { округов субъекта РФ, \% }\end{array}$ & 7,75 & 7,64 & 3,02 & 5,41 & 5,47 & 9,52 \\
\hline \multicolumn{7}{|c|}{ Город Зеленогорск (Красноярский край) } \\
\hline Местный бюджет, всего & 2290,8 & 2291,3 & $-0,5$ & 2281,2 & 2350,7 & $-69,5$ \\
\hline $\begin{array}{l}\text { Удельный вес в общем объеме } \\
\text { местных бюджетов субъекта } \\
\text { РФ, \% }\end{array}$ & 1,81 & 1,76 & 0,01 & 1,77 & 1,78 & 2,62 \\
\hline $\begin{array}{l}\text { Удельный вес в общем объеме } \\
\text { местных бюджетов городских } \\
\text { округов субъекта РФ, \% }\end{array}$ & 3,29 & 3,21 & 0,03 & 3,39 & 3,44 & 7,04 \\
\hline \multicolumn{7}{|c|}{ Город Заречный (Пензенская область) } \\
\hline Местный бюджет, всего & 2281,6 & 2326,4 & $-44,8$ & 2102,6 & 1983,1 & $+119,5$ \\
\hline $\begin{array}{l}\text { Удельный вес в общем объеме } \\
\text { местных бюджетов субъекта } \\
\text { РФ, \% }\end{array}$ & 8,20 & 6,74 & 0,67 & 6,86 & 6,66 & 13,36 \\
\hline
\end{tabular}


Продолжение табл. 2

\begin{tabular}{|c|c|c|c|c|c|c|}
\hline \multirow{2}{*}{ Показатель } & \multicolumn{3}{|c|}{ Бюджет на 2014 г. } & \multicolumn{3}{|c|}{ Бюджет на 2016 г. } \\
\hline & Доходы & Расходы & $\begin{array}{l}\text { Дефрицит (-), } \\
\text { профрицит (+) }\end{array}$ & Доходы & Расходы & $\begin{array}{l}\text { Десрицит (-), } \\
\text { профицит (+) }\end{array}$ \\
\hline $\begin{array}{l}\text { Удельный вес в общем объеме } \\
\text { местных бюджетов городских } \\
\text { округов субъекта РФ, \% }\end{array}$ & 15,95 & 11,28 & 0,71 & 13,16 & 12,53 & 76,32 \\
\hline \multicolumn{7}{|c|}{ Город Лесной (Свердловская область) } \\
\hline Местный бюджет, всего & 1947,9 & 2102,1 & $-154,2$ & 1863,4 & 2042,4 & $-179,0$ \\
\hline $\begin{array}{l}\text { Удельный вес в общем объеме } \\
\text { местных бюджетов субъекта } \\
\text { РФ, \% }\end{array}$ & 1,63 & 1,57 & 1,06 & 1,45 & 1,46 & 1,53 \\
\hline $\begin{array}{l}\text { Удельный вес в общем объеме } \\
\text { местных бюджетов городских } \\
\text { округов субъекта РФ, \% }\end{array}$ & 1,71 & 1,63 & 1,04 & 1,51 & 1,51 & 1,51 \\
\hline \multicolumn{7}{|c|}{ Город Новоуральск (Свердловская область) } \\
\hline Местный бюджет, всего & 4523,8 & 4501,9 & $+21,9$ & 3613,6 & 3613,6 & - \\
\hline $\begin{array}{l}\text { Удельный вес в общем объеме } \\
\text { местных бюджетов субъекта } \\
\text { РФ, \% }\end{array}$ & 3,79 & 3,36 & - & 2,81 & 2,58 & - \\
\hline $\begin{array}{l}\text { Удельный вес в общем объеме } \\
\text { местных бюджетов городских } \\
\text { округов субъекта РФ, \% }\end{array}$ & 3,97 & 3,50 & - & 2,94 & 2,68 & - \\
\hline \multicolumn{7}{|c|}{ Город Озерск (Челябинская область) } \\
\hline Местный бюджет, всего & 2948,5 & 2993,5 & $-45,0$ & 2930,5 & 2976,3 & $-45,8$ \\
\hline $\begin{array}{l}\text { Удельный вес в общем объеме } \\
\text { местных бюджетов субъекта } \\
\text { РФ, \% }\end{array}$ & 3,00 & 2,92 & 1,04 & 2,83 & 2,68 & 0,64 \\
\hline $\begin{array}{l}\text { Удельный вес в общем объеме } \\
\text { местных бюджетов городских } \\
\text { округов субъекта РФ, \% }\end{array}$ & 4,53 & 4,33 & 1,11 & 4,30 & 4,07 & 0,99 \\
\hline
\end{tabular}

Город Снежинск (Челябинская область)

\begin{tabular}{|l|r|r|r|r|r|r|}
\hline Местный бюджет, всего & 1976,1 & 2040,2 & $-64,1$ & 2064,5 & 2228,5 & $-164,0$ \\
\hline $\begin{array}{l}\text { Удельный вес в общем объеме } \\
\begin{array}{l}\text { местных бюджетов субъекта } \\
\text { РФ, \% }\end{array}\end{array} \quad 2,01$ & 1,99 & 1,48 & 1,99 & 2,01 & 2,28 \\
\hline $\begin{array}{l}\text { Удельный вес в общем объеме } \\
\begin{array}{l}\text { местных бюджетов городских } \\
\text { округов субъекта РФ, \% }\end{array}\end{array}$ & 3,04 & 2,95 & 1,58 & 3,02 & 3,05 & 3,54 \\
\hline
\end{tabular}

Город Трехгорный (Челябинская область)

\begin{tabular}{|c|c|c|c|c|c|c|}
\hline Местный бюджет, всего & 1187,8 & 1310,8 & $-123,0$ & 1332,3 & 1350,0 & $-17,7$ \\
\hline $\begin{array}{l}\text { Удельный вес в общем объеме } \\
\text { местных бюджетов субъекта } \\
\text { РФ, \% }\end{array}$ & 1,21 & 1,28 & 2,84 & 1,28 & 1,22 & 0,25 \\
\hline $\begin{array}{l}\text { Удельный вес в общем объеме } \\
\text { местных бюджетов городских } \\
\text { округов субъекта РФ, \% }\end{array}$ & 1,83 & 1,90 & 3,02 & 1,95 & 1,85 & 0,38 \\
\hline \multicolumn{7}{|c|}{ Город Саров (Нижегородская область) } \\
\hline Местный бюджет, всего & 3101,0 & 3183,0 & $-82,0$ & 2815,2 & 3001,8 & $-186,6$ \\
\hline $\begin{array}{l}\text { Удельный вес в общем объеме } \\
\text { местных бюджетов субъекта } \\
\text { РФ, \% }\end{array}$ & 3,79 & 3,20 & 0,47 & 3,39 & 3,29 & 2,32 \\
\hline
\end{tabular}




\begin{tabular}{|c|c|c|c|c|c|c|}
\hline \multirow{3}{*}{ Показатель } & & & & & Or & ончание табл. 2 \\
\hline & \multicolumn{3}{|c|}{ Бюджет на 2014 г. } & \multicolumn{3}{|c|}{ Бюджет на 2016 г. } \\
\hline & Доходы & Расходы & $\begin{array}{l}\text { Дефиицит (-), } \\
\text { профрицит (+) }\end{array}$ & Доходы & Расходы & $\begin{array}{l}\text { Дефиицит (-), } \\
\text { профрицит (+) }\end{array}$ \\
\hline $\begin{array}{l}\text { Удельный вес в общем объеме } \\
\text { местных бюджетов городских } \\
\text { округов субъекта РФ, \% }\end{array}$ & 6,95 & 5,84 & 0,83 & 5,64 & 5,81 & 10,89 \\
\hline \multicolumn{7}{|c|}{ Город Северск (Томская область) } \\
\hline Местный бюджет, всего & 3353,9 & 3283,7 & $+70,2$ & 3588,1 & 3558,1 & - \\
\hline $\begin{array}{l}\text { Удельный вес в общем объеме } \\
\text { местных бюджетов субъекта } \\
\text { РФ, \% }\end{array}$ & 9,81 & 9,10 & - & 9,96 & 10,22 & - \\
\hline $\begin{array}{l}\text { Удельный вес в общем объеме } \\
\text { местных бюджетов городских } \\
\text { округов субъекта РФ, \% }\end{array}$ & 17,67 & 15,17 & - & 17,89 & 18,34 & - \\
\hline
\end{tabular}

Составлена по данным: Об утверждении отчета об исполнении бюджета ЗАТО Железногорск за 2014 год : решение Совета депутатов ЗАТО г. Железногорск от 28.05.2015 г. № 57-298Р ; О бюджете ЗАТО г. Железногорск на 2016 год и плановый период 2017-2018 годов : решение Совета депутатов ЗАТО г. Железногорск от 15.12.2015 г. № 5-17P ; О местном бюджете города Зеленогорска на 2014 год и плановый период 2015-2016 годов : решение Совета депутатов ЗАТО г. Зеленогорска Краснояр. края от 19.12.2013 г. № 45-262p ; Об утверждении отчета об исполнении местного бюджета города Зеленогорска за 2016 год : решение Совета депутатов ЗАТО г. Зеленогорска Краснояр. края от 02.06.2017 г. № 39-217р ; О бюджете закрытого административно-территориального образования г. Заречный Пензенской области на 2014 год и плановый период 2015-2016 годы : решение Собр. представителей закрытого адм.-территор. образования г. Заречного Пенз. обл. от 24.12.2013 г. № 453 ; О бюджете закрытого административно-территориального образования г. Заречный Пензенской области на 2016 год : решение Собр. представителей закрытого адм.-территор. образования г. Заречного Пенз. обл. от 24.12.2015 г. № 114 ; О бюджете городского округа «Город Лесной» на 2014 год и плановый период 2015 и 2016 годов : решение Думы гор. окр. «Город Лесной» от 18.12.2013 г. № 225 ; О бюджете городского округа «Город Лесной» на 2016 год : решение Думы гор. окр. «Город Лесной» от 16.12.2015 г. № 415 ; О бюджете Новоуральского городского округа на 2014 год и плановый период 2015 и 2016 годов : решение Думы Новоур. гор. окр. от 04.12.2013 г. № 155 ; О бюджете Новоуральского городского округа на 2016 год : решение Думы Новоур. гор. окр. от 02.12.2015 г. № 148 ; О бюджете Озерского городского округа на 2014 год и на плановый период 2015 и 2016 годов : решение Собр. депутатов Озерского гор. окр. от 18.12.2013 г. № 222 ; О бюджете Озерского городского округа на 2016 год : решение Собр. депутатов Озерского гор. окр. от 25.12.2015 г. № 258 ; Об утверждении бюджета Снежинского городского округа на 2014 год и плановый период 2015 и 2016 годов : решение Собр. депутатов г. Снежинска от 19.12.2013 г. № 133 ; Об утверждении бюджета Снежинского городского округа на 2016 год : решение Собр. депутатов г. Снежинска от 24.12.2015 г. № 57 ; О бюджете города Сарова на 2014 год : решение Гор. Думы г. Сарова от 19.12.2013 г. № 109/5-гд ; О бюджете города Сарова на 2016 год : решение Гор. Думы г. Сарова от 25.12.2015 г. № 58/6-гд ; О бюджете ЗАТО Северск на 2014 год и на плановый период 2015 и 2016 годов : решение Думы ЗАТО Северск от 19.12.2013 г. № 47 /4; О бюджете ЗАТО Северск на 2016 год : решение Думы ЗАТО Северск от 24.12.2015 г. № 8 /1 ; О бюджете Трехгорного городского округа на 2014 год и на плановый период 2015 и 2016 годов : решение Собр. депутатов г. Трехгорного Челяб. обл. от 26.12.2013 г. № 92 ; О бюджете Трехгорного городского округа на 2016 год : решение Собр. депутатов г. Трехгорного Челяб. обл. от 11.12.2015 г. № 102.

Анализ представленных показателей позволяет выявить ряд тенденций в процессах формирования местных бюджетов закрытых атомных городов. Положение бюджетов закрытых атомных городов в общих показателях доходов местных бюджетов соответствующих субъектов РФ, а также в общих показателях местных бюджетов городских округов соответствующих субъектов РФ в рассматриваемом периоде является достаточно стабильным. Тем не менее происходит уменьшение доли присутствия местных бюджетов закрытых атомных городов в показателях доходов местных бюджетов (размах вариации от 0,02 п. п. до 4,67 п. п.). Данную тенденцию демонстрируют все города, за исключением г. Трехгорного. По показателям расходов ситуация практически противоположная, так как по шести городам из десяти наблюдается увеличение присутствия в общих показателях местных бюджетов (размах вариации от 0,01 п. п. до 0,63 п. п.). Данные тенденции подтверждаются также показателями дефицитов местных бюджетов закрытых атомных городов. Такая ситуация свидетельствует об ухудшении бюджетной обеспеченности закрытых атомных городов.

Отметим, что закрытые атомные города как вид ЗАТО являются получателями межбюджетных трансфертов из федерального бюджета бюджетам ЗАТО, что определено ст. 5.1 Закона о ЗАТО. Причем объемы и формы таких межбюджетных трансфрертов утверждаются фредеральным законом о федеральном бюджете на очередной финансовый год, что означает существование 
лишь методики распределения выделенного объема межбюджетных трансфертов между бюджетами ЗАТО. Дотации на компенсацию дополнительных расходов, связанных с особым режимом безопасного функционирования ЗАТО, перечисляемые из федерального бюджета бюджетам ЗАТО, имеют четко выраженную тенденцию к сокращению (табл. 3).

За период 2014-2018 гг. они сократились в номинальном выражении на 20,88 \%, что, очевидно, связано с сокращением ко- личества ЗАТО [11], и в плановом периоде 2019-2020 гг. также намечено их дальнейшее сокращение.

Между тем безвозмездные поступления являются самым крупным источником доходов бюджетов закрытых атомных городов (табл. 4). Например, в местных бюджетах рассматриваемых городских округов, утвержденных на 2018 г., доля безвозмездных поступлений варьирует от $69,8 \%$ в бюджете гг. Железногорска и Северска до 80,7 \% в бюджете г. Заречного.

Таблица 3

Дотации на компенсацию дополнительных расходов, связанных с особым режимом безопасного функционирования ЗАТО, из федерального бюджета в 2014-2018 гг. и на плановый период 2019-2020 гг.

\begin{tabular}{|c|r|r|}
\hline Год & Объем дотации, млн р. & Темп роста, \% \\
\hline 2014 & 11565,87 & 86,87 \\
\hline 2015 & 10047,16 & 86,87 \\
\hline 2016 & 10047,16 & 81,70 \\
\hline 2017 & 9449,35 & 79,12 \\
\hline 2018 & 9150,96 & 77,40 \\
\hline 2019 & 8952,02 & 77,40 \\
\hline 2020 & 8952,02 & 2015 \\
\hline
\end{tabular}

* Составлена по данным: О федеральном бюджете на 2014 год и на плановый период 2015 и 2016 годов : федер. закон от 02.12.2013 г. № 349-Ф3 ; О федеральном бюджете на 2015 год и на плановый период 2016 и 2017 годов : федер. закон от 01.12.2014 г. № 384-Ф3 ; О федеральном бюджете на 2016 год : федер. закон от 14.12.2015 г. № 359-Ф3; О федеральном бюджете на 2017 год и на плановый период 2018 и 2019 годов : федер. закон от 19.12.2016 г. № 415-Ф3; О федеральном бюджете на 2018 год и на плановый период 2019 и 2020 годов : федер. закон от 05.12.2017 г. № 362-Ф3.

Структура доходной части бюджетов закрытых атомных городов в 2014-2018 гг.

Таблица 4

\begin{tabular}{|c|c|c|c|c|c|c|c|c|c|}
\hline \multirow{2}{*}{ Показатель } & \multicolumn{3}{|c|}{ Налоговые доходы } & \multicolumn{3}{|c|}{ Неналоговые доходы } & \multicolumn{3}{|c|}{ Безвозмездные поступления } \\
\hline & 2014 & 2016 & 2018 & 2014 & 2016 & 2018 & 2014 & 2016 & 2018 \\
\hline \multicolumn{10}{|c|}{ Город Железногорск } \\
\hline $\begin{array}{l}\text { Сумма, } \\
\text { тыс. p. }\end{array}$ & 816010,2 & 797614,5 & 858706,6 & 232821,8 & 151540,4 & 167619,0 & 4351880,4 & 2689765,4 & 2376043,9 \\
\hline $\begin{array}{l}\text { Удельный } \\
\text { вес в общем } \\
\text { объеме } \\
\text { доходов, \% }\end{array}$ & 15,1 & 21,9 & 25,2 & 4,3 & 4,2 & 4,9 & 80,6 & 73,9 & 69,8 \\
\hline \multicolumn{10}{|c|}{ Город Зеленогорск } \\
\hline $\begin{array}{l}\text { Сумма, } \\
\text { тыс. р. }\end{array}$ & 547604,8 & 415237,4 & 437081,0 & 101664,8 & 75659,2 & 67063,3 & 1641573,8 & 1790256,2 & 1640396,6 \\
\hline $\begin{array}{l}\text { Удельный } \\
\text { вес в общем } \\
\text { объеме } \\
\text { доходов, \% }\end{array}$ & 23,9 & 18,2 & 20,4 & 4,4 & 3,3 & 3,1 & 71,7 & 78,5 & 76,5 \\
\hline \multicolumn{10}{|c|}{ Город Лесной } \\
\hline $\begin{array}{l}\text { Сумма, } \\
\text { тыс. р. }\end{array}$ & 555164,2 & 686629,5 & 499662,0 & 560980,5 & 138210,4 & 145928,7 & 831787,5 & 1038574,2 & 1537354,3 \\
\hline $\begin{array}{l}\text { Удельный } \\
\text { вес в общем } \\
\text { объеме } \\
\text { доходов, \% }\end{array}$ & 28,5 & 36,9 & 22,9 & 28,8 & 7,4 & 6,7 & 42,7 & 55,7 & 70,4 \\
\hline
\end{tabular}


Окончание табл. 4

\begin{tabular}{|c|c|c|c|c|c|c|c|c|c|}
\hline \multirow{2}{*}{ Показатель } & \multicolumn{3}{|c|}{ Налоговые доходы } & \multicolumn{3}{|c|}{ Неналоговые доходы } & \multicolumn{3}{|c|}{ Безвозмездные поступления } \\
\hline & 2014 & 2016 & 2018 & 2014 & 2016 & 2018 & 2014 & 2016 & 2018 \\
\hline \multicolumn{10}{|c|}{ Город Новоуральск } \\
\hline $\begin{array}{l}\text { Сумма, } \\
\text { тыс. p. }\end{array}$ & 853608,1 & 1122356,8 & 950325,7 & 116579,4 & 129751,0 & 121629,2 & 3553610,6 & 2361538,0 & 2895986,2 \\
\hline $\begin{array}{l}\text { Удельный } \\
\text { вес в общем } \\
\text { объеме } \\
\text { доходов, \% }\end{array}$ & 18,9 & 31,1 & 23,9 & 2,6 & 3,6 & 3,1 & 78,5 & 65,3 & 73,0 \\
\hline \multicolumn{10}{|c|}{ Город Северск } \\
\hline $\begin{array}{l}\text { Сумма, } \\
\text { тыс. р. }\end{array}$ & 698751,1 & 780138,9 & 884320,4 & 140185,5 & 175310,6 & 146437,8 & 2514970,4 & 2632647,2 & 2387301,7 \\
\hline $\begin{array}{l}\text { Удельный } \\
\text { вес в общем } \\
\text { объеме } \\
\text { доходов, \% }\end{array}$ & 20,8 & 21,7 & 25,9 & 4,2 & 4,9 & 4,3 & 75,0 & 73,4 & 69,8 \\
\hline \multicolumn{10}{|c|}{ Город Снежинск } \\
\hline $\begin{array}{l}\text { Сумма, } \\
\text { тыс. р. }\end{array}$ & 356736,4 & 346170,4 & 459646,2 & 89788,9 & 54589,7 & 63530,6 & 1529560,8 & 1663773,3 & 1695461,6 \\
\hline $\begin{array}{l}\text { Удельный } \\
\text { вес в общем } \\
\text { объеме } \\
\text { доходов, \% }\end{array}$ & 18,1 & 16,8 & 20,7 & 4,5 & 2,6 & 2,9 & 77,4 & 80,6 & 76,4 \\
\hline
\end{tabular}

" Составлена по данным: Об утверждении отчета об исполнении бюджета ЗАТО Железногорск за 2014 год : решение Совета депутатов ЗАТО г. Железногорск от 28.05.2015 г. № 57-298Р ; О бюджете ЗАТО г. Железногорск на 2016 год и плановый период 2017-2018 годов : решение Совета депутатов ЗАТО г. Железногорск от 15.12.2015 г. № 5-17P ; О бюджете ЗАТО Железногорск на 2018 год и плановый период 2019-2020 годов : решение Совета депутатов ЗАТО г. Железногорск от 14.12.2017 г. № 26-104P ; О местном бюджете города Зеленогорска на 2014 год и плановый период 2015-2016 годов : решение Совета депутатов ЗАТО г. Зеленогорска Краснояр. края от 19.12.2013 г. № 45-262p ; Об утверждении отчета об исполнении местного бюджета города Зеленогорска за 2016 год : решение Совета депутатов ЗАТО г. Зеленогорска Краснояр. края от 02.06.2017 г. № 39-217p ; О местном бюджете города Зеленогорска на 2018 год и плановый период 2019-2020 годов : решение Совета депутатов ЗАТО г. Зеленогорска Краснояр. края от 18.12.2017 г. № 46-259p ; О бюджете закрытого административно-территориального образования г. Заречный Пензенской области на 2014 год и плановый период 2015-2016 годы : решение Собр. представителей закрытого адм.-территор. образования г. Заречного Пенз. обл. от 24.12.2013 г. № 453 ; О бюджете закрытого административно-территориального образования г. Заречный Пензенской области на 2016 год : решение Собр. представителей закрытого адм.-территор. образования г. Заречного Пенз. обл. от 24.12.2015 г. № 114 ; О бюджете закрытого административно-территориального образования г. Заречный Пензенской области на 2018 год и плановый период 2019-2020 годов : решение Собр. представителей закрытого адм.-территор. образования г. Заречного Пенз. обл. от 22.12.2017 г. № 302 ; О бюджете городского округа «Город Лесной» на 2014 год и плановый период 2015 и 2016 годов : решение Думы гор. окр. «Город Лесной» от 18.12.2013 г. № 225 ; О бюджете городского округа «Город Лесной» на 2016 год : решение Думы гор. окр. «Город Лесной» от 16.12.2015 г. № 415 ; О бюджете городского округа «Город Лесной» на 2018 год и плановый период 2019 и 2020 годов : решение Думы гор. окр. «Город Лесной» от 20.12.2017 г. № 35 ; О бюджете Новоуральского городского округа на 2014 год и плановый период 2015 и 2016 годов : решение Думы Новоур. гор. окр. от 04.12.2013 г. № 155 ; О бюджете Новоуральского городского округа на 2016 год : решение Думы Новоур. гор. окр. от 02.12.2015 г. № 148 ; О бюджете Новоуральского городского округа на 2018 год и плановый период 2019 и 2020 годов : решение Думы Новоур. гор. окр. от 13.12.2017 г. № 174 ; О бюджете Озерского городского округа на 2014 год и на плановый период 2015 и 2016 годов : решение Собр. депутатов Озерского гор. окр. от 18.12.2013 г. № 222 ; О бюджете Озерского городского округа на 2016 год : решение Собр. депутатов Озерского гор. окр. от 25.12.2015 г. № 258 ; О бюджете Озерского городского округа на 2018 год и на плановый период 2019 и 2020 годов : решение Собр. депутатов Озерского гор. окр. от 07.12.2017 г. № 252 ; Об утверждении бюджета Снежинского городского округа на 2014 год и плановый период 2015 и 2016 годов : решение Собр. депутатов г. Снежинска от 19.12.2013 г. № 133 ; Об утверждении бюджета Снежинского городского округа на 2016 год : решение Собр. депутатов г. Снежинска от 24.12.2015 г. № 57 ; Об утверждении бюджета Снежинского городского округа на 2018 год и плановый период 2019 и 2020 годов : решение Собр. депутатов г. Снежинска от 21.12.2017 г. № 161 ; О бюджете города Сарова на 2014 год : решение Гор. Думы г. Сарова от 19.12.2013 г. № 109/5-гд ; О бюджете города Сарова на 2016 год : решение Гор. Думы г. Сарова от 25.12.2015 г. № 58/6-гд ; О бюджете города Сарова на 2018 год и на плановый период 2019 и 2020 годов : решение Гор. Думы г. Сарова от 15.12.2017 г. № 121 / 6-гд ; О бюджете ЗАТО Северск на 2014 год и на плановый период 2015 и 2016 годов : решение Думы ЗАТО Северск от 19.12.2013 г. № 47 / 4 ; О бюджете ЗАТО Северск на 2016 год : решение Думы ЗАТО Северск от 24.12.2015 г. № 8/1; О бюджете ЗАТО Северск на 2018 год и на плановый период 2019 и 2020 годов : решение Думы ЗАТО Северск от 21.12.2013 г. № 33/1; О бюджете Трехгорного городского округа на 2014 год и на плановый период 2015 и 2016 годов : решение Собр. депутатов г. Трехгорного Челяб. обл. от 26.12.2013 г. № 92 ; О бюджете Трехгорного городского округа на 2018 год : решение Собр. депутатов г. Трехгорного Челяб. обл. от 11.12.2015 г. № 102 ; О бюджете Трехгорного городского округа на 2016 год : решение Собр. депутатов г. Трехгорного Челяб. обл. от 28.11.2017 г. № 109. 
В. Н. Сусликов и Е. В. Позднякова отмечают, что, «если мы рассматриваем в целом муниципальные образования, можно однозначно сказать, что на сегодняшний день создан работающий механизм, который позволяет обеспечить самостоятельность органов местного самоуправления при формировании, распределении и использовании местных бюджетов и в то же время их взаимодействие путем межбюджетного трансферта с бюджетами субъектов, а через них с бюджетом Российской Федерации. ....Непосредственно после принятия в 1992 г. Ф3 № 3297-1 «О закрытом административно-территориальном образовании» было заложено довольно много гарантий самостоятельности ЗАТО по сравнению с остальными муниципальными образованиями. До конца 90-х годов прошлого века на территориях, входивших в состав ЗАТО, все налоги, взимаемые с этих территорий, зачислялись непосредственно в бюджеты ЗАТО, также был предусмотрен целый комплекс других льгот. В ходе реформирования федерального законодательства в начале прошлого десятилетия все они были постепенно отменены, что не могло не сказаться весьма негативным образом на бюджетах ЗАТО, попавших в большую зависимость от федерального центра» [12, с. 142].

Безвозмездные поступления в местных бюджетах ЗАТО формируются за счет трех видов межбюджетных трансфертов - дотаций, субсидий и субвенций. Но в отличие от местных бюджетов открытых муниципальных образований сюда поступают дотации из федерального бюджета на компенсацию дополнительных расходов, связанных с особым режимом безопасного функционирования ЗАТО.

Особый режим безопасного функционирования организаций и объектов в ЗАТО включает:

- во-первых, в пределах территории ЗАТО или по ее границе могут устанавливаться контролируемые и (или) запретные зоны;

- во-вторых, вводятся ограничения на въезд и (или) постоянное проживание граждан на территории ЗАТО, в том числе устанавливается перечень оснований для отказа во въезде или в постоянном проживании;

- в-третьих, ограничиваются полеты летательных аппаратов над территорией ЗАТО;

- в-четвертых, предусматриваются ограничения на право ведения хозяйственной и предпринимательской деятельности, владения, пользования и распоряжения природными ресурсами, недвижимым имуществом, обусловленные ограничениями на въезд и (или) постоянное проживание;
- в-пятых, существуют ограничения на создание и деятельность на территории ЗАТО организаций, связанных с иностранным капиталом;

- в-шестых, организуется разработка и осуществление мер по предупреждению терроризма, предотвращению техногенных катастроф, обеспечению пожарной безопасности и охране общественного порядка.

Таким образом, межбюджетные трансферты бюджетам ЗАТО предоставляются на дополнительные расходы, связанные с режимом его безопасного фрункционирования и потерей доходов в связи с ограничением права ведения хозяйственной и предпринимательской деятельности, владения, пользования и распоряжения природными ресурсами, недвижимым имуществом, а также с развитием и поддержкой социальной и инженерной инфраструктуры. Дотации на компенсацию дополнительных расходов и (или) потерь бюджетов ЗАТО, связанных с особым режимом безопасного функционирования, предоставляются бюджетам ЗАТО при условии реализации органами местного самоуправления программ комплексного социально-экономического развития ЗАТО. Структура безвозмездных поступлений в местных бюджетах закрытых атомных городов в динамике представлена в табл. 5.

Таблица 5

Структура безвозмездных поступлений в местных бюджетах закрытых атомных городов в 2014-2018 гг., \%

\begin{tabular}{|l|r|r|r|r|r|}
\hline \multirow{5}{*}{$\begin{array}{c}\text { Вид безвоз- } \\
\text { мездных }\end{array}$} & \multicolumn{5}{|c|}{ Удельный вес в объеме } \\
безвозмездных поступлений, \% \\
\cline { 2 - 6 } Город Железногорск \\
\hline Дотации & 2014 & 2015 & 2016 & 2017 & 2018 \\
\hline Субсидии & 4,9 & 0,6 & 0,06 & 0,6 & 6,7 \\
\hline Субвенции & 39,6 & 52,3 & 62,5 & 57,2 & 54,3 \\
\hline \multicolumn{5}{|c|}{ Город Заречный } \\
\hline Дотации & 69,6 & $\ldots$ & 65,6 & 63,1 & 56,6 \\
\hline Субсидии & - & - & - & - & - \\
\hline Субвенции & 30,4 & $\ldots$ & 34,4 & 36,9 & 43,4 \\
\hline \multicolumn{5}{|c|}{ Город Зеленогорск } \\
\hline Дотации & 42,6 & 35,9 & 38,5 & 41,5 & 40,6 \\
\hline Субсидии & 7,6 & 28,3 & 15,7 & 8,3 & 7,8 \\
\hline Субвенции & 49,7 & 35,8 & 45,0 & 50,2 & 51,6 \\
\hline \multicolumn{5}{|c|}{ Город Лесной } \\
\hline Дотации & 17,3 & 12,8 & 12,6 & 6,3 & 4,6 \\
\hline Субсидии & 4,2 & 35,4 & 11,8 & 27,3 & 38,5 \\
\hline Субвенции & 78,2 & 51,6 & 75,6 & 66,4 & 56,8 \\
\hline \multicolumn{5}{|c|}{ Город Новоуральск } \\
\hline Дотации & 28,4 & 37,3 & 34,5 & 28,3 & 20,0 \\
\hline Субсидии & 37,0 & 15,8 & 3,5 & 14,2 & 24,1 \\
\hline
\end{tabular}


Окончание табл. 5

\begin{tabular}{|c|c|c|c|c|c|}
\hline \multirow{2}{*}{$\begin{array}{c}\text { Вид безвоз- } \\
\text { мездных } \\
\text { поступлений }\end{array}$} & \multicolumn{5}{|c|}{$\begin{array}{c}\text { Удельный вес в объеме } \\
\text { безвозмездных поступлений, \% }\end{array}$} \\
\hline & 2014 & 2015 & 2016 & 2017 & 2018 \\
\hline Субвенции & 34,5 & 46,8 & 61,8 & 56,8 & 50,7 \\
\hline \multicolumn{6}{|c|}{ Город Озерск } \\
\hline Дотации & 25,4 & 39,3 & 22,6 & 24,1 & 23,8 \\
\hline Субсидии & 14,7 & 0,8 & 13,1 & 8,8 & 10,3 \\
\hline убвениии & 59,8 & 59,8 & 64,3 & 67,1 & 65,9 \\
\hline \multicolumn{6}{|c|}{ Город Северск } \\
\hline Дотации & 51,3 & 49,1 & 48,0 & 53,3 & 52,7 \\
\hline Субсидии & 8,9 & 12,9 & 13,3 & 4,5 & 3,8 \\
\hline $\mathrm{Cy}$ & 39,5 & 37,7 & 38,6 & 42,0 & 43,3 \\
\hline \multicolumn{6}{|c|}{ Город Снежинск } \\
\hline Дотаь & 35,8 & 50,4 & 38,1 & 36,9 & 35,2 \\
\hline Субсидии & 12,6 & 0,7 & 13,0 & 10,2 & 11,2 \\
\hline Субвенции & 51,2 & 48,7 & 48,8 & 52,9 & 53,6 \\
\hline \multicolumn{6}{|c|}{ Город Трехгорный } \\
\hline Дотации & 35,1 & 38,0 & 32,1 & 33,3 & 32,7 \\
\hline Субсидии & 9,2 & 8,5 & 13,9 & 10,1 & 11,2 \\
\hline Субвенции & 55,0 & 52,8 & 54,0 & 56,6 & 56,1 \\
\hline
\end{tabular}

Анализ динамики структуры безвозмездных поступлений в местных бюджетах закрытых атомных городов позволяет сделать вывод о том, что на протяжении рассматриваемого периода структура по группе данных городов в целом сохраняет свою идентичность: среди видов безвозмездных поступлений преобладают субвенции, на втором месте находятся дотации и на третьем месте по величине удельного веса - субсидии. Тенденция, которую демонстрируют все рассматриваемые города, за исключением г. Лесного, заключается в росте удельного веса субвенций в общем объеме безвозмездных поступлений. Масса структурного сдвига составила: г. Новоуральск - 16,2 п. п., г. Железногорск $-14,7$ п. п., г. Заречный - 13 п. п., г. Озерск - 6,1 п. п., г. Северск - 3,8 п. п., г. Снежинск - 2,4 п. п., г. Зеленогорск 1,9 п. п, г. Трехгорный - 1,1 п. п.

С целью конкретизации рассмотренной выше информации представим абсолютные и относительные показатели в табл. 6.

Таблица 6

Безвозмездные поступления в местных бюджетах закрытых атомных городов, утвержденные решениями о бюджетах на 2018 г.

\begin{tabular}{|c|c|c|c|c|}
\hline \multirow[b]{3}{*}{$\begin{array}{c}\text { Безвоз- } \\
\text { мездные } \\
\text { поступления, } \\
\text { всего }\end{array}$} & \multicolumn{4}{|c|}{ В том числе } \\
\hline & \multicolumn{2}{|r|}{ Дотации } & \multirow[b]{2}{*}{ Субсидии } & \multirow[b]{2}{*}{ Субвенции } \\
\hline & Всего & $\begin{array}{c}\text { В том числе дотации } \\
\text { на компенсацию дополнитель- } \\
\text { ных расходов, связанных } \\
\text { с особым режимом безопас- } \\
\text { ного фуннционирования ЗАТО }\end{array}$ & & \\
\hline \multicolumn{5}{|c|}{ Город Железногорск } \\
\hline 2376043,9 & 927412,6 & 917779,0 & 159098,3 & 1289533,0 \\
\hline 100,0 & 39,0 & 38,6 & 6,7 & 54,3 \\
\hline \multicolumn{5}{|c|}{ Город Заречный } \\
\hline 1688943,0 & 955298,0 & 920664,0 & - & 733645,0 \\
\hline 100,0 & 56,6 & 54,5 & - & 43,4 \\
\hline \multicolumn{5}{|c|}{ Город Зеленогорск } \\
\hline 1640396,6 & 666557,7 & 532866,0 & 127890,2 & 845948,7 \\
\hline 100,0 & 40,6 & 32,5 & 7,8 & 51,6 \\
\hline 1537354,3 & 71363,0 & 63721,0 & 592433,0 & 873558,3 \\
\hline 100,0 & 4,6 & 4,1 & 38,5 & 56,8 \\
\hline \multicolumn{5}{|c|}{ Город Новоуральск } \\
\hline 2895986,2 & 580143,0 & 310075,0 & 698604,9 & 1467238,3 \\
\hline 100,0 & 20,0 & 10,7 & 24,1 & 50,7 \\
\hline \multicolumn{5}{|c|}{ Город Озерск } \\
\hline 2315574,3 & 550341,0 & 456473,0 & 239621,9 & 1525611,4 \\
\hline 100,0 & 23,8 & 19,7 & 10,3 & 65,9 \\
\hline \multicolumn{5}{|c|}{ Город Северск } \\
\hline 2387301,7 & 1258122,5 & 770161,0 & 89823,3 & 1032843,8 \\
\hline 100,0 & 52,7 & 32,3 & 3,8 & 43,3 \\
\hline \multicolumn{5}{|c|}{ Город Снежинск } \\
\hline 1695461,6 & 596701,0 & 549889,0 & 189879,0 & 908881,6 \\
\hline 100,0 & 35,2 & 32,4 & 11,2 & 53,6 \\
\hline
\end{tabular}


Окончание табл. 6

\begin{tabular}{|c|c|c|c|c|c|}
\hline \multirow[b]{3}{*}{ Показатель } & \multirow[b]{3}{*}{$\begin{array}{c}\text { Безвоз- } \\
\text { мездные } \\
\text { поступления, } \\
\text { всего }\end{array}$} & \multicolumn{4}{|c|}{ В том числе } \\
\hline & & \multicolumn{2}{|r|}{ Дотации } & \multirow[b]{2}{*}{ Субсидии } & \multirow[b]{2}{*}{ Субвенции } \\
\hline & & Всего & $\begin{array}{c}\text { В том числе дотации } \\
\text { на компенсацию дополнитель- } \\
\text { ных расходов, связанных } \\
\text { с особым режимом безопас- } \\
\text { ного функционирования ЗАТО }\end{array}$ & & \\
\hline \multicolumn{6}{|c|}{ Город Трехгорный } \\
\hline Сумма, тыс. р. & 871515,2 & & 284888,0 & 252579,0 & 97448,1 \\
\hline Удельный вес, \% & 100,0 & & 32,7 & 29,0 & 11,2 \\
\hline
\end{tabular}

" Составлена по данным: О бюджете ЗАТО Железногорск на 2018 год и плановый период 2019-2020 годов : решение Совета депутатов ЗАТО г. Железногорск от 14.12.2017г. № 26-104Р ; О местном бюджете города Зеленогорска на 2018 год и плановый период 2019-2020 годов : решение Совета депутатов ЗАТО г. Зеленогорска Краснояр. края от 18.12.2017 г. № 46-259p ; О бюджете закрытого административно-территориального образования г. Заречный Пензенской области на 2018 год и плановый период 2019-2020 годов : решение Собр. представителей закрытого адм.-территор. образования г. Заречного Пенз. обл. от 22.12.2017 г. № 302 ; О бюджете городского округа «Город Лесной» на 2018 год и плановый период 2019 и 2020 годов : решение Думы гор. окр. «Город Лесной» от 20.12.2017 г. № 35 ; О бюджете Новоуральского городского округа на 2018 год и плановый период 2019 и 2020 годов : решение Думы Новоур. гор. окр. от 13.12.2017 г. № 174 ; О бюджете Озерского городского округа на 2018 год и на плановый период 2019 и 2020 годов : решение Собр. депутатов Озерского гор. окр. от 07.12.2017 г. № 252 ; Об утверждении бюджета Снежинского городского округа на 2018 год и плановый период 2019 и 2020 годов : решение Собр. депутатов г. Снежинска от 21.12.2017 г. № 161 ; О бюджете ЗАТО Северск на 2018 год и на плановый период 2019 и 2020 годов : решение Думы ЗАТО Северск от 21.12.2013 г. № 33/1; О бюджете Трехгорного городского округа на 2016 год : решение Собр. депутатов г. Трехгорного Челяб. обл. от 28.11.2017 г. № 109.

Как видно из представленных в табл. 6 данных, размеры дотаций варьируют от 63,7 млн р. в бюджете г. Лесного до 920,7 млн р. в бюджете г. Заречного. Такой размах вариации обусловлен рядом факторов, учитываемых при определении размера дотации, а именно:

- численность населения закрытого атомного города;

- коэфрфициент удорожающих или удешевляющих фракторов (индекс бюджетных расходов, используемый для распределения дотаций на выравнивание бюджетной обеспеченности субъектов Российской Федерации, и другие поправочные коэффицциенты, устанавливаемые Министерством фринансов Российской Федерации для учета особенностей расходных обязательств отдельных ЗАТО);

- расчетная стоимость износа объектов социальной и инженерной инфраструктуры на территории закрытого атомного города;

- размер расходов бюджета закрытого атомного города, необходимый для доведения уровня обеспеченности объектами до уровня, установленного нормативами;

- полная учетная стоимость основных фондов организаций муниципальной формы собственности, находящихся на территории закрытого атомного города;

- фактическая обеспеченность объектами социальной и инженерной инфраструктуры в расчете на 1 чел.;

- средняя стоимость создания единицы мощности соответствующих объектов, утвержденная в установленном порядке (укрупненные сметные нормативы (показатели)) или рассчитанная на основании стоимостных показателей по объектам-аналогам.

С учетом факта сокращения объемов дотаций из федерального бюджета на компенсацию дополнительных расходов, связанных с особым режимом безопасного функционирования ЗАТО, в период 2014-2018 гг. наблюдается тенденция сокращения доли данного вида дотаций в общем объеме безвозмездных поступлений в бюджеты закрытых городов: в Трехгорном - с 34,7 до $29,0 \%$, Снежинске - с 35,5 до 32,4\%, Северске - с 41,0 до 32,3\%, Озерске - с 30,0 до $19,7 \%$, Новоуральске - с 14,7 до $10,7 \%$, Лесном - с 15,9 до 4,1 \%, Зеленогорске - с 35,2 до $32,5 \%$, Заречном - с 68,9 до 54,5\%.

В структуре безвозмездных поступлений в местных бюджетах закрытых городов преобладают субвенции, предоставляемые на исполнение органами местного самоуправления ЗАТО отдельных государственных полномочий, в том числе в сфере образования, здравоохранения, социальной поддержки, жилищно-коммунального хозяйства. Среди субвенций самыми крупными являются субвенции на финансовое обеспечение государственных гарантий прав граждан на получение общедоступного и бесплатного дошкольного образования в муниципальных дошкольных образовательных организациях и субвенции на финансовое обеспечение государственных гарантий прав граждан на получение общедоступного и бесплатного дошкольного, начального об- 
щего, основного общего, среднего общего образования в муниципальных общеобразовательных организациях и фринансовое обеспечение дополнительного образования детей в муниципальных образовательных организациях (табл. 7).

Таблица 7

Субвенции в структуре местных бюджетов закрытых атомных городов

\begin{tabular}{|c|c|c|c|}
\hline Вид субвенций & 2014 & 2016 & 2018 \\
\hline \multicolumn{4}{|l|}{ Город Железногорск } \\
\hline Субвенции, всего, тыс. р. & 1721894,3 & 1682351,0 & 1289533,0 \\
\hline $\begin{array}{l}\text { Субвенции на финансовое обеспечение государственных гарантий } \\
\text { реализации прав граждан на получение общедоступного и бесплат- } \\
\text { ного общего и дополнительного образования в МОО }\end{array}$ & $\cdots$ & 396702,7 & 426099,4 \\
\hline Доля, \% & & 23,6 & 33,0 \\
\hline $\begin{array}{l}\text { Субвенции на финансовое обеспечение государственных гарантий } \\
\text { реализации прав граждан на получение общедоступного и бесплат- } \\
\text { ного дошкольного образования в МДОО }\end{array}$ & $\cdots$ & 536787,8 & 532224,0 \\
\hline Доля, \% & & 31,9 & 41,3 \\
\hline $\begin{array}{l}\text { Субвенции на реализацию отдельных мер по обеспечению ограни- } \\
\text { чения платы граждан за коммунальные услуги }\end{array}$ & $\cdots$ & 643018,3 & 183847,7 \\
\hline Доля, \% & & 38,2 & 14,3 \\
\hline
\end{tabular}

Город Заречный

Субвенции, всего, тыс. р.

Субвенции на финансовое обеспечение государственных гарантий реализации прав граждан на получение общедоступного и бесплатного общего и дополнительного образования в МОО

Доля, \%

Субвенции на финансовое обеспечение государственных гарантий реализации прав граждан на получение общедоступного и бесплатного дошкольного образования в МДОО

Доля, \%

Субвенции на обеспечение мер социальной поддержки ветеранов труда и тружеников тыла

Доля, \% Город Зеленогорск

Субвенции, всего, тыс. $\mathrm{p}$

Субвенции на финансовое обеспечение государственных гарантий реализации прав граждан на получение общедоступного и бесплатного общего и дополнительного образования в МОО

Доля, \%

Субвенции на финансовое обеспечение государственных гарантий реализации прав граждан на получение общедоступного и бесплатного дошкольного образования в МДОО

Доля, \%

Город Лесной

Субвенции, всего, тыс. р.

Субвенции на финансовое обеспечение государственных гарантий реализации прав граждан на получение общедоступного и бесплатного общего и дополнительного образования в МОО

Доля, \%

Субвенции на финансовое обеспечение государственных гарантий реализации прав граждан на получение общедоступного и бесплатного дошкольного образования в МДОО

Доля, \%

Субвенции на осуществление государственного полномочия

Свердловской области по предоставлению отдельным категориям граждан компенсаций расходов на оплату жилого помещения и коммунальных услуг

Доля, \%

Город Новоуральск

Субвенции, всего, тыс. р.

\begin{tabular}{|r|r|r|}
\hline 557009,0 & 590015,7 & 733645,0 \\
\hline 156709,4 & 140506,5 & 169400,4 \\
\hline 28,1 & 23,8 & 23,1 \\
\hline 162119,8 & 181129,1 & 206449,9 \\
\hline 29,1 & 30,7 & 28,1 \\
\hline 121298,4 & 151720,9 & 179993,2 \\
\hline 21,8 & 25,7 & 24,5 \\
\hline
\end{tabular}

\begin{tabular}{|r|r|r|}
\hline 815456,7 & 805778,6 & 845948,7 \\
\hline 257101,6 & 316862,0 & 321091,4 \\
\hline 31,5 & 39,3 & 37,9 \\
\hline 224302,7 & 383948,1 & 387005,1 \\
\hline 27,5 & 47,6 & 45,7 \\
\hline
\end{tabular}

\begin{tabular}{|l|l|l|}
\hline 650634,3 & 784957,9 & 873558,3 \\
\hline
\end{tabular}

\begin{tabular}{l|l|l}
292812,0 & 290202,0 & 341305,0
\end{tabular}

\begin{tabular}{|r|r|r|} 
& & 341305,0 \\
\hline 45,0 & 37,0 & 39,1 \\
\hline
\end{tabular}

\begin{tabular}{l|l|l}
\hline 188762,0 & 320987,0 & 319815,0
\end{tabular}

\begin{tabular}{|r|r|r|}
\hline 29,0 & 40,9 & 36,6 \\
\hline
\end{tabular}

\begin{tabular}{l|l|l}
$97908,0 \quad 108102,0$ & 137543,0
\end{tabular}

\begin{tabular}{l|r|r|}
15,0 & 13,8 & 15,7 \\
\hline
\end{tabular}

\begin{tabular}{|l|l|l|l|l|}
\hline Субвенции, всего, тыс.р. & 1226380,0 & 1459382,5 & 1467238,3 \\
\hline
\end{tabular}


Продолжение табл. 7

\begin{tabular}{|c|c|c|c|}
\hline Вид субвенций & 2014 & 2016 & 2018 \\
\hline $\begin{array}{l}\text { Субвенции на финансовое обеспечение государственных гарантий } \\
\text { реализации прав граждан на получение общедоступного и бесплат- } \\
\text { ного общего и дополнительного образования в МОО }\end{array}$ & 596665,0 & 633857,0 & 638352,0 \\
\hline Доля, \% & 48,7 & 43,4 & 43,5 \\
\hline $\begin{array}{l}\text { Субвенции на финансовое обеспечение государственных гарантий } \\
\text { реализации прав граждан на получение общедоступного и бесплат- } \\
\text { ного дошкольного образования в МДОО }\end{array}$ & 365123,0 & 546355,0 & 498532,0 \\
\hline Доля, \% & 29,8 & 37,4 & 34,0 \\
\hline $\begin{array}{l}\text { Субвенции на осуществление государственного полномочия } \\
\text { Свердловской области по предоставлению отдельным категориям } \\
\text { граждан компенсаций расходов на оплату жилого помещения и } \\
\text { коммунальных услуг }\end{array}$ & 168692,0 & 195726,0 & 253474,0 \\
\hline Доля, \% & 13,8 & 13,4 & 17,3 \\
\hline \multicolumn{4}{|l|}{ Город Северск } \\
\hline Субвенции, всего, тыс. р. & 993852,8 & 1016591,9 & 1032843,8 \\
\hline $\begin{array}{l}\text { Субвенции на финансовое обеспечение государственных гарантий } \\
\text { реализации прав граждан на получение общедоступного и бесплат- } \\
\text { ного общего и дополнительного образования в МОО }\end{array}$ & 425218,0 & 512127,0 & 533121,2 \\
\hline Доля, \% & 42,8 & 50,4 & 51,6 \\
\hline $\begin{array}{l}\text { Субвенции на финансовое обеспечение государственных гарантий } \\
\text { реализации прав граждан на получение общедоступного и бесплат- } \\
\text { ного дошкольного образования в МДОО }\end{array}$ & 422301,9 & 399487,4 & 407918,2 \\
\hline Доля, \% & 42,5 & 39,3 & 39,5 \\
\hline \multicolumn{4}{|l|}{ Город Снежинск } \\
\hline Субвенции, всего, тыс. р. & 783721,9 & 812298,6 & 908881,6 \\
\hline $\begin{array}{l}\text { Субвенции на финансовое обеспечение государственных гарантий } \\
\text { реализации прав граждан на получение общедоступного и бесплат- } \\
\text { ного общего и дополнительного образования в МОО }\end{array}$ & 184700,8 & 193447,2 & 219530,7 \\
\hline Доля, \% & 23,6 & 23,8 & 24,2 \\
\hline $\begin{array}{l}\text { Субвенции на финансовое обеспечение государственных гарантий } \\
\text { реализации прав граждан на получение общедоступного и бесплат- } \\
\text { ного дошкольного образования в МДОО }\end{array}$ & 264430,7 & 294146,7 & 337310,4 \\
\hline Доля, \% & 33,7 & 36,2 & 37,1 \\
\hline $\begin{array}{l}\text { Субвенции на обеспечение мер социальной поддержки ветеранов } \\
\text { труда и тружеников тыла }\end{array}$ & 126299,6 & 129109,1 & 148474,2 \\
\hline Доля, \% & 16,1 & 15,9 & 16,3 \\
\hline \multicolumn{4}{|l|}{ Город Трехгорный } \\
\hline Субвенции, всего, тыс. р. & 427242,2 & 454501,3 & 489179,1 \\
\hline $\begin{array}{l}\text { Субвенции на финансовое обеспечение государственных гарантий } \\
\text { реализации прав граждан на получение общедоступного и бесплат- } \\
\text { ного общего и дополнительного образования в МОО }\end{array}$ & 110569,2 & 124318,9 & 133086,3 \\
\hline Доля, \% & 25,9 & 27,4 & 27,2 \\
\hline $\begin{array}{l}\text { Субвенции на финансовое обеспечение государственных гарантий } \\
\text { реализации прав граждан на получение общедоступного и бесплат- } \\
\text { ного дошкольного образования в МДОО }\end{array}$ & 123955,6 & 129166,2 & 138819,8 \\
\hline Доля, \% & 29,0 & 28,4 & 28,4 \\
\hline $\begin{array}{l}\text { Субвенции на обеспечение мер социальной поддержки ветеранов } \\
\text { труда и тружеников тыла }\end{array}$ & 75833,5 & 82386,8 & 88115,6 \\
\hline Доля, \% & 17,8 & 18,1 & 18,0 \\
\hline
\end{tabular}

" Составлена по данным: Об утверждении отчета об исполнении бюджета ЗАТО Железногорск за 2014 год : решение Совета депутатов ЗАТО г. Железногорск от 28.05.2015 г. № 57-298Р ; О бюджете ЗАТО г. Железногорск на 2016 год и плановый период 2017-2018 годов : решение Совета депутатов ЗАТО г. Железногорск от 15.12.2015 г. № 5-17Р ; О бюджете ЗАТО Железногорск на 2018 год и плановый период 2019-2020 годов : решение Совета депутатов ЗАТО г. Железногорск от 14.12.2017 г. №26-104P ; О местном бюджете города Зеленогорска на 2014 год и плановый период 2015-2016 годов : решение Совета депутатов ЗАТО г. Зеленогорска Краснояр. края от 19.12.2013 г. № 45-262p ; Об утверждении отчета об исполнении местного бюджета города Зеленогорска за 2016 год : решение Совета депутатов ЗАТО г. Зеленогорска Краснояр. края от 02.06.2017 г. № 39-217p ; О местном бюджете города Зеленогорска на 2018 год и плановый период 2019-2020 годов : решение Совета депутатов ЗАТО г. Зеленогорска Краснояр. края от 18.12.2017 г. № 46-259p ; О бюджете закрытого административно-территориального образования г. Заречный Пензенской области на 2014 год и плановый период 2015-2016 годов : решение Собр. представителей 
Окончание табл. 7

закрытого адм.-территор. образования г. Заречного Пенз. обл. от 24.12.2013 г. № 453 ; О бюджете закрытого административно-территориального образования г. Заречный Пензенской области на 2016 год : решение Собр. представителей закрытого адм.-территор. образования г. Заречного Пенз. обл. от 24.12.2015 г. № 114 ; О бюджете закрытого административно-территориального образования г. Заречный Пензенской области на 2018 год и плановый период 2019-2020 годов : решение Собр. представителей закрытого адм.-территор. образования г. Заречного Пенз. обл. от 22.12.2017 г. № 302 ; О бюджете городского округа «Город Лесной» на 2014 год и плановый период 2015 и 2016 годов : решение Думы гор. окр. «Город Лесной» от 18.12.2013 г. № 225 ; О бюджете городского округа «Город Лесной» на 2016 год : решение Думы гор. окр. «Город Лесной» от 16.12.2015 г. № 415 ; О бюджете городского округа «Город Лесной» на 2018 год и плановый период 2019 и 2020 годов : решение Думы гор. окр. «Город Лесной» от 20.12.2017 г. № 35 ; О бюджете Новоуральского городского округа на 2014 год и плановый период 2015 и 2016 годов : решение Думы Новоур. гор. окр. от 04.12.2013 г. № 155 ; О бюджете Новоуральского городского округа на 2016 год : решение Думы Новоур. гор. окр. от 02.12.2015 г. № 148 ; О бюджете Новоуральского городского округа на 2018 год и плановый период 2019 и 2020 годов : решение Думы Новоур. гор. окр. от 13.12.2017 г. № 174 ; О бюджете ЗАТО Северск на 2014 год и на плановый период 2015 и 2016 годов : решение Думы ЗАТО Северск от 19.12.2013 г. №47/4 ; О бюджете ЗАТО Северск на 2016 год : решение Думы ЗАТО Северск от 24.12.2015 г. № 8/1; О бюджете ЗАТО Северск на 2018 год и на плановый период 2019 и 2020 годов : решение Думы ЗАТО Северск от 21.12.2013 г. № 33/1; Об утверждении бюджета Снежинского городского округа на 2014 год и плановый период 2015 и 2016 годов : решение Собр. депутатов г. Снежинска от 19.12.2013 г. № 133 ; Об утверждении бюджета Снежинского городского округа на 2016 год : решение Собр. депутатов г. Снежинска от 24.12.2015 г. № 57 ; Об утверждении бюджета Снежинского городского округа на 2018 год и плановый период 2019 и 2020 годов : решение Собр. депутатов г. Снежинска от 21.12.2017 г. № 161 ; О бюджете Трехгорного городского округа на 2014 год и на плановый период 2015 и 2016 годов : решение Собр. депутатов г. Трехгорного Челяб. обл. от 26.12.2013 г. № 92 ; О бюджете Трехгорного городского округа на 2018 год : решение Собр. депутатов г. Трехгорного Челяб. обл. от 11.12.2015 г. № 102 ; О бюджете Трехгорного городского округа на 2016 год : решение Собр. депутатов г. Трехгорного Челяб. обл. от 28.11.2017 г. № 109.

В анализируемом периоде наблюдается тенденция к росту совокупного удельного веса субвенций на финансовое обеспечение государственных гарантий общедоступного и бесплатного общего и дошкольного образования в общем объеме субвенций, предоставляемых местным бюджетам: г. Железногорск - с 62,3 до 74,3\%, г. Зеленогорск - с 59,0 до $83,6 \%$, г. Лесной - с 74,0 до 75,7 \%, г. Северск - с 85,3 до 91,1\%, г. Снежинск с 57,3 до $61,3 \%$, г. Трехгорный - с 54,9 до $55,6 \%$. Кроме субвенций на реализацию полномочий в сорере образования, к крупным субвенциям следует отнести: субвенции на обеспечение мер социальной поддержки ветеранов труда и тружеников тыла; субвенции на оплату жилищно-коммунальных услуг отдельным категориям граждан; субвенции на финансирование расходов по социальному обслуживанию граждан, в том числе по предоставлению мер социальной поддержки работникам муниципальных учреждений социального обслуживания.

В целях софинансирования расходных обязательств, возникающих при выполнении полномочий органов местного самоуправления по вопросам местного значения, из бюджета субъекта Российской Федерации местным бюджетам ЗАТО предоставляются субсидии. В структуре местных бюджетов анализируемой группы городов, утвержденных на 2018 г., удельный вес субсидий в общем объеме безвозмездных поступлений варьирует от 3,8 \% в бюджете г. Северска до 38,5 \% в бюджете г. Лесного. Факторами, обусловливающими такой размах вариации, выступают различия в конкретных видах и объемах субсидий, поступающих в местные бюджеты соответствующих городов. Например, для бюджета г. Северска наиболее крупной межбюджетной субсидией в размере 27,091 млн р. является субсидия на создание дополнительных мест во вновь построенных образовательных организациях с использованием механизма государственно-частного партнерства в рамках государственной программы «Развитие образования в Томской области». А в бюджете г. Лесного крупнейшей субсидией является межбюджетная субсидия на выравнивание обеспеченности муниципальных образований, расположенных на территории Свердловской области, по реализации ими отдельных расходных обязательств в размере 549,9 млн р.

Подводя итоги, отметим, что межбюджетные трансферты являются основным доходным источником местных бюджетов закрытых атомных городов, и при сохранении существующих подходов к формированию местных бюджетов и направлений бюджетно-налоговой политики их значение не ослабнет и в прогнозируемом периоде. В результате проведенного эмпирического исследования выявлены следующие тенденции:

- уменьшение доли присутствия местных бюджетов закрытых атомных городов в показателях доходов местных бюджетов;

- преобладание субвенций среди видов безвозмездных поступлений, на втором месте находятся дотации и на третьем месте по величине удельного веса - субсидии, 
причем наблюдается тенденция $к$ росту удельного веса субвенций в общем объеме безвозмездных поступлений.

В Основных направлениях бюджетной, налоговой и таможенно-тарифной политики РФ на 2018 год и плановый период 2019 и 2020 годов предусматривается повышение эфрфективности системы межбюджетных трансфертов за счет создания предсказуемых, прозрачных и комфортных условий предоставления финансовой помощи, своевременного ее доведения до регионов, а следовательно, и до уровня муниципальных образований.

\section{СПИСОК ИСПОЛЬЗОВАННОЙ ЛИТЕРАТУРЫ}

1. Закрытые атомные города России / Е. Г. Анимица [и др.]. - Екатеринбург : Изд-во Урал. гос. экон. ун-та, 2002. - 186 с.

2. Анимица Е. Г. Региональные аспекты новой индустриализации / Е. Г. Анимица, Я. П. Силин, Н. В. Новикова / / Экономика региона. - 2017. - Т. 13, вып. 3. - С. 684-696.

3. Силин Я. П. Российская модель новой индустриализации: к постановке проблемы / Я. П. Силин, Е. Г. Анимица // Известия Уральского государственного экономического университета. - 2017. № 5 (73). - C. 44-53.

4. Карачков С. М. Закрытый «атомный город». Дух корпоративности и модель управления / С. М. Карачков, А. И. Зверев. - М. : Геоинформ, 2017. - 232 с.

5. Кузнецов В. Н. Атомные закрытые административно-территориальные образования Урала. История и современность / В. Н. Кузнецов. - Екатеринбург : Банк культур. информации, 2016. - Ч. 2 : Постсоветский период. - $386 \mathrm{c}$.

6. Мельникова Н. В. Феномен закрытого атомного города / Н. В. Мельникова. - Екатеринбург : Банк культур. информации, 2006. - Вып. 42 : Очерки истории Урала. - 176 с.

7. Файков Д. Ю. Закрытые административно-территориальные образования. «Атомные» города / Д. Ю. Файков. - Саров : Изд-во Рос. федер. ядер. центра - ВНИИ эксперим. фиизки, 2010. - 269 с.

8. Левина В. В. Использование финансовых инструментов регулирования регионального развития: проблемы и перспективы / В. В. Левина / / Управленец. - 2017. — № 3 (67). - С. 18-24.

9. Прокофьев М. Н. Оценка эффрективности межбюджетных трансфертов при формировании местных бюджетов / М. Н. Прокофьев, К. Ю. Багратуни / / Муниципальная академия. — 2017. — № 4. - С. 90-96.

10. Пронина Л. И. Муниципалитеты: налоги, межбюджетные трансферты из федерального бюджета в 2018-2020 гг. / Л. И. Пронина / / Экономика и управление: проблемы, решения. — 2017. — Т. 2, № 12. — C. $10-16$.

11. Дьякова Е. В. Особенности формирования местных бюджетов закрытых административнотерриториальных образований / Е. В. Дьякова, О. В. Немировская, О. А. Гражданкина / / Экономика устойчивого развития. - 2017. - № 2 (30). - С. 116-123.

12. Сусликов В. Н. Особенности бюджетного процесса в закрытых административно-территориальных образованиях / В. Н. Сусликов, Е. В. Позднякова // Известия Юго-Западного государственного университета. - 2015. - Т. 1, № 3 (60). - С. 140-143.

\section{REFERENCES}

1. Animitsa E. G., Vlasova N. Yu., Dvoryadkina E. B., Novikova N. V., Sofronov V. N. Zakrytye atomnye goroda Rossii [Russian Closed Atomic Cities]. Yekaterinburg, Ural State University of Economics Publ., 2002. 186 p.

2. Animitsa E. G., Silin Ya. P., Novikova N. V. Regional Aspects of New Industrialization. Ekonomika regiona = Economy of Region, 2017, vol. 13, iss. 3, pp. 684-696. (In Russian).

3. Silin Ya. P., Animitsa E. G. Russian Model of New Industrialization: on the Problem Statement. Izvestiya Ural' skogo gosudarstvennogo ekonomicheskogo universitetata = Journal of the Ural State University of Economics, 2017, no. 5 (73), pp. 44-53. (In Russian).

4. Karachkov S. M., Zverev A. I. Zakrytyi «atomnyi gorod». Dukh korporativnosti i model upravleniya [A Closed "Atomic City». Corporativity Genius and Management Model]. Moscow, Geoinform Publ., 2017. 232 p.

5. Kuznetsov V. N. Atomnye zakrytye administrativno-territorialnye obrazovaniya Urala. Istoriya i sovremennost' [Closed Atomic Administrative Territorial Entities of Ural. History and Our Times]. Yekaterinburg, Bank kulturnoi informatsii Publ., 2016. Pt. 2. 386 p.

6. Melnikova N. V. Fenomen zakryłogo atomnogo goroda [Closed Atomic City Phenomenon]. Yekaterinburg, Bank kulturnoi informatsii Publ., 2006. Iss. 42.176 p.

7. Faikov D. Yu. Zakrytye administrativno-territorialnye obrazovaniya. «Atomnye» goroda [Closed Administrative Territorial Entities. "Atomic» Cities.]. Sarov, Russian federal nuclear center All-Russian research institute of experimental physics Publ., 2010. 269 p.

8. Levina V. V. Using Financial Tools of Regional Development Regulation: Problems and Perspectives. Upravlenets = The Manager, 2017, no. 3 (67), pp. 18-24. (In Russian).

9. Prokofev M. N., Bagratuni K. Yu. Efficiency Evaluation of Inter-Budgetary Transfers When Forming Local Budgets. Munitsipalnaya akademiya = Municipal Academy, 2017, no. 4, pp. 90-96. (In Russian).

10. Pronina L. I. Municipality: Taxes, Inter-Budgetary Transfers from the Federal Budget in 2018-2020. Ekonomika i upravlenie: problemy, resheniya = Economics and Management: problems and solutions, 2017, vol. 2, no. 12, pp. 10-16. (In Russian). 
11. Dyakova E. V., Nemirovskaya O. V., Grazhdankina O. A. Formation Peculiarities of Local Budgets of Closed Administrative Territorial Entities. Ekonomika ustoichivogo razvitiya = The Economics of Sustainable Development, 2017, no. 2 (30), pp. 116-123. (In Russian).

12. Suslikov V. N., Pozdnyakova E. V. Budget Process Peculiarities in Closed Administrative Territorial Entities. Izvestiya Yugo-Zapadnogo gosudarstvennogo universiteta = Proceedings of the Southwest state university, 2015, vol. 1, no. 3 (60), pp. 140-143. (In Russian).

\section{Информация об авторе}

Дворядкина Елена Борисовна - доктор экономических наук, профессор, проректор по научной работе, кафедра региональной, муниципальной экономики и управления, Уральский государственный экономический университет, 620144, г. Екатеринбург, ул. 8 Марта / Народной Воли, 62/45, e-mail: Elena.dvoryadkina@yandex.ru.

\section{Для цитирования}

Дворядкина Е. Б. Межбюджетные трансорерты в структуре бюджетов закрытых атомных городов - территорий новой индустриализации: эмпирическое исследование / Е. Б. Дворядкина // Известия Байкальского государственного университета. - 2018. - T. 28, № 2. - C. 186-200. - DOI: 10.17150/2500-2759.2018.28.(2).186-200.

\section{Author}

Elena B. Dvoryadkina - D.Sc. in Economics, Professor, Vice Rector for Research, Regional, Municipal Economy and Governance Department, Ural State University of Economics, 62/45 8 Marta / Narodnoy Voli St., 620144, Yekaterinburg, the Russian Federation, e-mail: elena.dvoryadkina@yandex.ru.

\section{For citation}

Dvoryadkina E. B. Intergovernmental Transfers in the Structure of Limited-Access Atomic Cities' Budgets as Territories of the New Industrialization: an Empirical Study. Izvestiya Baykal'skogo gosudarstvennogo universiteta $=$ Bulletin of Baikal State University, 2018, vol. 28, no. 2, pp. 186-200. DOI: $10.17150 / 2500-$ 2759.2018.28.(2).186-200. (In Russian). 